Editorial

\title{
Trans* Politics: Current Challenges and Contestations Regarding Bodies, Recognition, and Trans* Organising
}

\author{
Mieke Verloo * and Anna van der Vleuten \\ Department of Political Science, Radboud University, 6525AJ Nijmegen, The Netherlands; \\ E-Mails: m.verloo@fm.ru.nl (M.V.), a.vandervleuten@fm.ru.nl (A.v.d.V.) \\ * Corresponding author
}

Submitted: 14 September 2020 | Published: 18 September 2020

\begin{abstract}
This thematic issue analyses trans* politics, and the problems and policies articulated by societal, political and legal actors in national and international contexts in Europe and Latin America. Trans* issues are at the heart of politics concerning sex and gender, because the sex binary ordering is producing the categories, identities, and related social relationships around which gender inequalities are constructed. Scholarship on trans* politics promises to bring more fundamental knowledge about how the gender binary organisation of our societies is (dis)functional, and is therefore relevant and beneficial for all gender and politics scholarship. Contestations around trans* issues continue developing, between state and non-state actors, transgender people and medical professionals, and also among and between social movements. This thematic issue is our contribution to dimensions of trans* politics that revolve around the issue of sexed and gendered bodies (the making and unmaking of "deviant" bodies, non-binary language about bodies, and voice given in bodily re/assignments), the limits of recognition (undermining of trans* agency, persistent binary thinking, and disconnect with material dimensions of gender justice), and the potential of trans* movements (processes and practices through which political claims are generated in the movement, a more forward looking and pro-active perspective on the possibility of alliances between the feminist and the trans* projects, and between the trans* project and the disability project, and alliances of movement actors with institutional power holders such as international courts).
\end{abstract}

\section{Keywords}

binary; sex; sexuality; social movements; trans*; transgender; transgender recognition; transgender politics

Issue

This editorial is part of the issue "Trans* Politics: Current Challenges and Contestations" edited by Mieke Verloo (Radboud University, the Netherlands) and Anna van der Vleuten (Radboud University, the Netherlands).

(C) 2020 by the authors; licensee Cogitatio (Lisbon, Portugal). This article is licensed under a Creative Commons Attribution 4.0 International License (CC BY).

\section{Introduction}

There are many reasons why trans* issues are at the heart of politics concerning sex and gender. A first and major one is that sex binary ordering is producing the categories, identities, and related social relationships around which gender inequalities are constructed (Tilly, 1998). Trans* issues challenge the binary sex categories and the social and political allocation of people to these categories. They do so socially and politically. Through the unveiling of their individual troubles in the social world with the classic binary sex identities, trans peo- ple unavoidably contest these identities as two stable categories, "man" and "woman." This binary ordering is deeply engrained in society and constantly reproduced by law, architecture, education, daily practices and formal and informal institutions. Through the demands of the movements on trans* rights to transform these categories, wider societal changes are set in motion, accompanied by renewed social and political debates. Together, these processes make visible and tangible what it means when we say that sex categories are socially and politically constructed, and unveil that-on top of resulting in highly problematic gender inequalities-this causes 
harm and suffering for trans people that could be undone by nothing less than reorganising society.

A second reason why trans* issues are at the heart of politics concerning sex and gender is that trans* issues move them into unknown territory: What could and should be done to reorganise society is in no way evident, and is still in the process of being imagined both in terms of what needs to be done and how it can be done without causing yet more harm, suffering or inequality. More attention to trans* issues hence promises to bring more fundamental knowledge about how the gender binary organisation of our societies is (dis)functional, and is therefore relevant and beneficial for all gender and politics scholarship. This thematic issue is our contribution to charting unknown territory.

With this thematic issue we aim to address current challenges and contestations regarding trans* politics in Europe and Latin America. Over the last decades, strong transnational advocacy networks of trans* people have developed, articulating their concerns. These concerns have reached national and international political agendas in a relatively rapid pace (Kollman \& Waites, 2009). In November 2006, an international group of human rights experts gathered in Indonesia and drafted the Yogyakarta Principles, a document that outlines the fundamental human rights of sexual and gender minorities (O'Flaherty \& Fisher, 2008). In the same year, the Declaration of Montreal was presented at the International Conference on LGBT Human Rights in Montreal, Canada. The Declaration, written primarily by activist and former Dutch politician Joke Swiebel, proposed to create a UN Convention on elimination of all forms of sexual orientation and gender identity discrimination, but the initiative was not successful (Kollman \& Waites, 2009). "Yogyakarta" was picked up in different parts of the world. In 2008, for instance, the General Assembly of the Organization of American States adopted unanimously the Brazil-sponsored resolution condemning human rights violations based on sexual orientation and gender identity. During the General Assembly, government representatives met with activists from Latin American LGBT organisations who pointed to how harassment and violence against the LGBT community continue throughout the Americas, and they underscored their concern about impunity and inaction by authorities (Human Rights Watch, 2008). The European Union and the Council of Europe took up the issue of discrimination on the base of gender identity as well, resulting in recommendations, reports, resolutions and a directive (Dunne, 2020).

Progress at the global level, however, has turned out to be difficult, because of staunch opposition from an "unholy alliance" of the Vatican, the United States, member states of the Organization of Islamic Cooperation and several African and Latin American states (Chappell, 2006; Kabeer, 2015). Despite the stated commitment of the UN 'to leave no one behind,' and despite relentless pressure by activists, the final version of the Sustainable
Development Goals does not acknowledge the existence of LGBT people nor their social exclusion (Vaast \& Mills, 2018 , p. 57). Yet, thanks to pressure by activists, international organisations and many states have developed policies addressing trans* issues in highly diverse domains such as gender recognition, anti-discrimination, marriage and family rights, access to primary and gender affirming medical care, combatting of gender-based violence and hate crimes (Ayoub, 2016). Finally, discrimination of trans* people and violation of their rights have been the subject of decisions, sometimes bold, sometimes disappointing, by international courts (de Waele \& van der Vleuten, 2011; Helfer \& Voeten, 2014).

However, in spite of considerable progress and support, the rights and concerns of trans* people continue to be challenged in different ways. While in 2019 the Dutch parliament adopted legislation tackling discrimination of transgender and intersex people, the Hungarian parliament decided to abolish legal gender recognition (Transgender Europe, 2020). While Malta became the first European state to add gender identity to its Constitution as a protected category (Dalli, 2014), the Bulgarian government decided not to ratify the Istanbul Convention of the Council of Europe to combat genderbased violence, because ratification was argued to increase the likelihood of young people identifying as transgender (Hervey, 2018).

Recurring processes of political contestation make clear how transgender concerns touch upon issues that are at the heart of how our societies are organised, socially and politically. In particular, transgender concerns upset medical thinking and practices in different ways, because transgender people defy conventional standards by asking for sometimes irreversible medical interventions in bodies which are considered healthy. Furthermore, these interventions may result in bodies which defy simple categorisation as male or female, thereby provoking contestations from medical professionals (Soto-Lafontaine, 2020), international judges (van der Vleuten, 2020) and society alike.

Contestations around trans* issues continue developing, between state and non-state actors, between transgender people and medical professionals, but also among and between social movements. Mobilisation around trans* issues has created unexpected alliances, for instance with disability activists (Elpes, 2020). It also has fuelled tensions within feminist and LGBTI movements, and has given rise to strong contestations, revolving around questions such as "who is a woman," and "who is entitled to speak on behalf of women" (see Hines, 2019; Jeffreys, 1997; Pearce, Erikainen, \& Vincent, 2020; see also Saeidzadeh \& Strid, 2020).

This thematic issue aims to shed light on these dimensions of trans* politics, analysing the problems and policies articulated by societal, political and legal actors in national and international contexts. This editorial situates the thematic issue within existing scholarship on transgender contestations. We theorise 
the central concepts-transgender, binary, trans*and highlight how the different contributions advance our understanding of contestations of trans* interests and identities.

\section{Concepts}

Language is performative. Words create identities, and each identity-creating term by definition includes some people and excludes others. It is privilege not to experience exclusion, and transgender people never enjoyed such privilege. In different times and places, they have been called different names, and have themselves adopted different names. Since the 1990s, "transgender" is the word most commonly used in academic literature and public debate to refer to transgender men (transmen), transgender women (transwomen) and non-binary persons (Bettcher, 2016). Transgender also includes cross-dressers or transvestites, who dress in clothes only associated with the opposite sex. The term "transsexual" is considered to be more specific than transgender, referring to a person who was assigned male (or female) at birth, identifies as woman (or man), and underwent medical treatment such as gender confirmation surgery and/or hormonal therapy with the aim to obtain congruence between gender identity and sex/body. Many transgender and transsexual people define themselves in binary terms. Yet, increasingly, people identify as transgender without seeking bodily transformation, without experiencing gender dysphoria and without identifying themselves in binary terms.

"Binary" refers to thinking in terms of two sexes, male and female, as mutually exclusive categories. "Non-binary" is used both for self-identification and as an umbrella term referring to all people who experience gender identities that are both male and female (bi-gender), neither male nor female (agender, genderless), genderfluid (having a fluctuating gender identity), genderqueer (a gender identity or expression which is transgressive and non-normative), queer (non-cisgender and/or not heterosexual), and others (Meier \& Motmans, 2020). While these concepts are being used since the 1990s, several concepts used in non-Western contexts are centuries old already, such as bissu (one of five genders among Bugis people in Indonesia), fa'afafine and fa'atane (Samoa), hijra (in Pakistan, India and Nepal; see Aboim, 2020), and māhū (in Hawaiian and Tahitian cultures; Babits, 2018).

In the titles of the thematic issue and this editorial, we have not opted for transgender but for trans* (pronounced as "trans asterisk" or "trans star"). Trans* explicitly includes non-binary identities, while transgender may be considered, fairly or unfairly, as referring only to binary non-cisgender people. Trans* has become increasingly common since the 2000s, as it is perceived as explicitly inclusive of all binary and non-binary non-cis people. Gender studies scholar Susan Stryker explains how trans* is 'a way of pointing to a somewhat related class of phe- nomena without having to articulate exactly what that is, or get into fine-grain distinctions' (Stryker, as cited in Steinmetz, 2018).

This thematic issue aims to use inclusionary language. Yet, we are aware that, as every concept, also "trans*" is contested, by people who feel that the asterisk is redundant, and by sexual and gender minorities in nonWestern cultures who feel that the concept does not do justice to how they experience gender. The articles in this thematic issue take this into account when referring to non-Western contexts (Aboim, 2020; Sosa, 2020) and also problematise terms used for (self-)identification. As editors we have refrained from imposing a single conceptualisation or terminology on all authors, and we have respected their choices.

\section{Contestations and Challenges: Contributions in this Thematic Issue}

A first set of articles addresses issues related to the trans* body, bringing new contributions that highlight how bodies have been talked about in trans* politics, address trans* politics of pleasure and sexuality, and carefully unpack how politics, laws and policies deal with trans violence.

A second set addresses issues related to the development of legal norms on the recognition of trans identities. Articles discuss the strengths, biases and limitations of legal codification and its unintended effects.

A third set, finally, explores the question how mobilisation based on gender identity leads to the development of successful alliances as well as tensions with other social movements. Such tensions are related to fundamental questions about sex and gender, identities and social status.

\subsection{Bodies and Embodiment}

Bodies and embodiment are at the heart of trans* politics. Given the deeply entrenched binary nature of the way our societies are organised and function, bodies are seen as primarily male or female, and people hence come as either men or women. Three questions then become crucial to conceptualise how the way bodies and embodiment are socially organised produces harm or inequality for trans* people, and gives rise to political dynamics that aim to address this. The first asks when bodies are normal, and when they are deviant or pathological. Here, trans* history shows that, given the primacy of the medical profession to deal with ailing bodies, medical professionals have been among the first to pioneer solutions for the suffering of trans* people, all the while creating a strong power base for themselves in trans* politics and occupying the space where the voice of trans people was then excluded. This history also shows that the conceptualisation of the body is always not just gendered but also sexualised, as a change of gender immediately clashes with heteronormatively organised societies. 
Even if there was agreement that a change of gender identity was needed, the hurdle of having to face nonheterosexual couples and families proved too much in almost all places. The pathologisation resulted in a joint gender and sexuality nexus of normality.

The second question asks how to develop a social and political language that enables articulating what happens to non-hegemonic bodies. This is visible in the surge of new concepts developed by opponents of trans* rights: autogynephilia (defined as the erotic interest in the thought of oneself as a woman), detransition (halting transition), and rapid-onset gender dysphoria (referring to an alleged epidemic of youth coming out as transgender due to social contagion and mental illness; see the special issue edited by Pearce et al. [2020] on the TERF-trans exclusionary radical feminist-wars). Also, legal language is still inarticulate when physical reproduction meets trans* rights and parenthood is not conventionally gendered (van der Vleuten, 2020).

The third question asks who gets a voice in bodily interventions, in social and political debates and decisions about bodies. Bodily interventions used to be done under the authority of anyone but the person concerned. While the medical professions were having the most powerful voice for a long time, currently there is a shift to more politicised voices, including the voices of trans people and trans movements. Change is ongoing, and in the hopefully not so far away future, dignity, bodily integrity and empowerment should be the only reasonable base to make decisions about bodily interventions, especially when suffering is present.

While all articles in this issue address these topics, the history of trans body politics in the Netherlands shows these three dimensions most clearly. Melisa Soto-Lafontaine (2020) investigates the different ways trans issues have been framed in the Netherlands. Across time, she shows how there was an early shift from seeing trans* people as suffering from mental illness, to a frame that saw their bodies as posing a problem for them, before a later understanding added that also society presents a problem because the hegemonic cisheteronormativity hinders alternative understandings of bodies. Her analysis offers a fascinating tale of how trans bodies came to be seen as deviant and the crucial importance of advocacy and voice of trans people to change dominant perception and language.

\subsection{Limits of Recognition}

Alongside medical and sexuality research, much scholarship regarding transgender issues focuses on trans human rights and legal gender recognition (for an overview, see Quinan, Molitor, van den Brink, \& Zimenkova, 2020). This should not come as a surprise, because legal recognition has been a core and recurrent theme in transgender political mobilisation and individual litigation, as it makes enjoyment of other rights, such as citizenship and democratic participation, possible (Sosa, 2020).
In the 1950s, soon after they obtained access to medical treatments, transgender people started asking for having their legal documents changed accordingly. Soto-Lafontaine (2020) shows how in the Netherlands in the 1970s, a change of gender marker was obtained by arguing in court that at birth a mistake had been made. The issue arose in other countries as well and resulted in cases in national and international courts. Litigation continues today regarding the conditions set to qualify for legal gender recognition, such as sterilisation, the obligation to undergo genital surgery, or the requirement to divorce (van der Vleuten, 2020).

Yet, recognition and litigation recognising trans* identity present inherent limits and biases. In this thematic issue we identify several of them: undermining of trans agency, persistent binary thinking, and disconnect with material dimensions of gender justice. Regarding agency, litigation about gender recognition tends to transfer the power to decide from transgender people to medical experts and judges (van der Vleuten, 2020). Platero (2020) notes how Spanish regional transgender laws often fall short regarding autonomy (depathologisation and self-determination) and authority (participation in policymaking processes) of transgender people. However, in some countries trans activists are reconquering autonomy. Soto-Lafontaine (2020) shows how Dutch transgender activists have been partially successful in having transgender people recognised as experts, care providers and political actors, although before the court legal and medical expertise continues to be valued higher. Even the revised Belgian transgender law (2017) has dropped all medical conditions and based the application procedure on self-determination (Meier \& Motmans, 2020). However, litigation continues because Belgian law continues to be plagued by another limitation which is common to most systems of gender registration: persisting binary linear thinking.

States and courts perpetuate linear binary thinking, allowing at most for female/male identity change or vice versa, and assigning citizenship rights to transmen and transwomen, but not to non-binary persons (Monro \& van der Ros, 2018). Sex registration is by definition linear unless it allows for easily repeatedly changing it, and it excludes non-binary people unless it adds a third marker. A growing number of states has over the past years adopted non-binary markers such as " $X$," "Other," and "Unspecified." Sofia Aboim (2020) zooms in on the state-controlled multiplication of official gender markers. She shows the paradox at work where the individual moral entitlement to difference has to be reconciled with a common political identity, leading to reified group identities. That said, adding a third option in a binary structured society might even exacerbate instead of eliminate stigma, discrimination and marginalisation (Meier \& Motmans, 2020).

States and courts are poorly equipped for dealing with non-binary and fluid gender identities, especially regarding parenthood. In a recent British case, for instance, 
a transgender man who had given birth wanted to be registered as the child's father. Yet, the court decided that 'motherhood is defined as being pregnant and giving birth regardless of whether the person who does so was considered a man or a woman in law' (Booth, 2020). The case shows how self-identification is rejected and how the court constructs motherhood: Pregnancy and giving birth simply are physical capacities, but the court states that the body which possesses these capacities by definition cannot belong to a father but constitutes motherhood. This illustrates once again the performative power of language.

Individual litigation by itself cannot change social structures of inequality, and Lucas Platero (2020) therefore argues that more attention should be paid to the material dimension. Trans* people need access to resources in order to enjoy their rights. Platero deplores how the recognition of trans* individuals as new political subjects has been separated from claims for economic justice. Without redistribution, recognition risks to confer merely symbolic rights, hence aggravating instead of remedying marginalisation and inequality. Court decisions aligned with trans* demands can contribute to norm change beyond the individual case when supported by political mobilisation, but they remain within the boundaries of legal systems. In the end, any categorisation inevitably entails misrecognition of some identities. This awareness has led to a more general contestation of categorisation and a call for 'abolishment of sex and gender registration altogether' (Quinan et al., 2020, p. 3; see also Baars, 2019; The New York Times, 2014). This strategy to break the boundaries of legal systems was also suggested, interestingly, by the highest Belgian court (Meier \& Motmans, 2020). Yet, for erasing its exclusionary nature, the abolishment of registration would need to go hand in hand with the abolishment of all binary institutionalisation, from toilets and hospitals to prisons, not to mention all routinely-and often arbitrarily-binary gendered practices in daily life. In sum, the articles in this thematic issue show in different ways how recognition by state and courts enables and constrains the construction of trans* identities, and has real, positive and negative, impacts on trans* lives.

\subsection{The Potential and Challenges of Organising and Mobilisation}

As stated in the introduction, trans* movements and political claim making on trans issues are crucial for trans* politics because they are the breeding ground for imagining a trans* inclusive society and charting new perspectives, as first steps in realizing such imagined better worlds. Imagining and claims-making are causing ongoing, essential social and political debates on the trouble with a sex binary way of organising society, and how to move beyond this. Scholarship on the role of trans mobilisation and organising is still rare. Some of the scholarship has a strong focus on transnational (European) organising, and incorporates attention for trans* mobilizing within a focus on gay and lesbian or queer politics (Ayoub \& Paternotte, 2014; Balzer \& Hutta, 2014; Bilić, 2016; van der Vleuten, 2014). Recently, clashes between trans organisations and feminist ones have been addressed explicitly (Pearce et al., 2020).

The articles presented here make three main contributions to our knowledge on trans* organising and mobilisation, both in terms of ideas generated, actors involved, alliances created or avoided, strategies developed and deployed, and potential success and failure of particular strategies. One, they investigate processes and practices through which political claims are generated in the movement; two, they present a more forwardlooking and pro-active perspective on the possibility of alliances (between the feminist and the trans* project, and between the trans and the disability projects); and three, they present studies that look into alliances of movement actors with institutional power holders such as courts.

Concerning the generation of ideas, and zooming in on the history of trans* politics in the Netherlands, Soto-Lafontaine (2020) offers a strong illustration that actors and ideas cannot be disentangled easily: medical professionals propose solutions that sit firmly within their expertise, legal specialists follow suit, while activists bring in a focus on support and mobilisation. And actors that have brought success in the past with solutions that bear their mark, hinder further progress that requires them to make space for other perspectives, other goals and other actors. This analysis shows the specific role that medical professionals of various backgrounds have in body politics (see Engeli, 2012, for a parallel on reproductive rights).

This history also shows an increasing role for trans* people themselves, who had little room for agency at first. Ludovico Virtù (2020) studies the trans* movement from within, in a social and political context that is remarkably open to it. His main focus is on how diagnostic and prognostic ideas are generated in a process of trans-organising in an informal collectivity. In his empirical analysis of micro-organisational processes, he analyses how, by putting trans* people centre stage and creating a space where they can celebrate 'the "chaos" of gender identities and experiences,' a small DIY sex toy workshop created new knowledge on sex, sexualities and bodies in ways that displace the binary, help create counterdiscourses and avoid commodification of sex, sexualities and bodies (Virtù, 2020, p. 322). His analysis uncovers the main strategies used to achieve this: dis/organising language, embodiment and knowledge, and using formativeness and personal vulnerability as methods. Most importantly, he underlines the importance of movements to create space for what could be called "performative imagination": the emergence of ideas while a practice is performed.

Recent scholarship on tensions between the feminist and the trans* projects has analysed a specific format 
that these tensions have acquired in mostly Anglophone settings: the so-called "TERF wars" (Pearce et al., 2020). This scholarship has a strong focus on opposition to trans* rights, and related to that also a strong re-active component, "debunking" concepts that are central to opposition to trans* rights, such as autogynephilia (Serano, 2020), rapid-onset gender dysphoria (Ashley, 2020) and detransition (Hildebrand-Chupp, 2020). In contrast, our thematic issue presents a more forward-looking perspective on the possibility of alliances between the trans project and other social justice projects such as the feminist project and the disability justice project. There are two main contributions. Zara Saeidzadeh and Sofia Strid's (2020) reflection on tensions, hostility and collaborations between the trans* and feminist projects, analyses the roots of this hostility and presents ideas that could generate a way out. Their analysis draws not only on the current tensions between feminist and trans* movements, but also on a (older) shared history of collaboration. They locate the roots of later but ongoing conflicts in diverging positions within law, activism and academia. In these divergences, they argue that identitybased politics as well as biological determinism are at the root of the antagonism. They argue that both feminist and trans* politics need to abandon an identity-based politics of recognition for alliances to be possible and productive. Abandoning a focus on specific categories of people (trans* people, or cis-feminists) in favour of a joint (and intersectional) struggle against sexism would also deconstruct 'the dichotomy of exclusionary anti-trans* feminism and inclusionary trans*-affirming feminism' (Saeidzadeh \& Strid, p. 316). Three elements are crucial: understanding recognition as status-based instead of identity-based, understanding interests as based on shared oppressions, and valuing political and coalitional strategies within and between social justice projects. Also Gustavo Santos Elpes zooms in on potential coalitions on trans* politics and sees a high potential for trans* politics to 'expand the political subject of feminism and our understanding of identity politics and embodied action' (Elpes, 2020). His reflections centre on the role of embodiment (see above), and also include attention for resonances and coalitions between trans* politics and the disability movement in Madrid, in which notions of self-care and caregiving are central. Instead of simplistic identity politics, and much in line with the call from Saeidzadeh and Strid (2020), he calls for a politics in which:

Trans* (binary and non-binary) people and disability activists approach social vulnerability in conjunction with the oppression experienced by non-normative bodies and identities, assuming a confrontational position in the face of an (instrumental) feminist agenda that resists adding some subjects as actors of feminist struggles (such as trans people or sex workers). (Elpes, 2020, p. 309)
Lastly, to make progress on trans* rights, not only alliances between social movements are needed, but also with actors in powerful institutions such as courts. Lorena Sosa (2020) analyses very carefully how legal concepts are strongly linked to certain actors, how they can hinder or facilitate such alliances and can have a strong impact on outcomes. She also shows the importance of informal collaborations within institutional settings, such as the ad hoc commission composed of family members, trans* activists and other allies with the prosecution office after the murder of trans* activist Diana Sacayán.

\section{Conclusion and Discussion}

Trans* issues are at the heart of trans* politics and at the heart of studies on sex and gender, but not (yet) at the heart of political science in Europe and Latin America. There might be several causes for this: a general understanding of sexed and gendered bodies as natural and, hence, by definition not political; a false equation of politics with "what politicians do" obscuring absences in political debate; a stronger attention for the powerful than for the subordinated or subaltern in political science; or a hesitation of academics to be too close to the fire of current contestations.

A first difficulty might be related to a fundamentally essentialist way of looking at bodies, as if they are so ultimately and exclusively materially natural that it does not matter how we understand them. Yet, history learns otherwise. Whether it is about the history of sex and gender relations, the history of sexuality and the various ways it has been normalised and restricted, or the history of identities that defy a binary understanding of sex or that question an understanding of sex as always more true than gender: All these histories unmask such an essentialist understanding of sex and gender, and their concomitant social institutionalisation as incongruent with people's actual live experiences and their potential to lead a fulfilling and productive social life.

The difficult acceptance and late emergence of queer issues and queer theorizing within the discipline of political science have already been documented (Paternotte, 2018). Accepting the social nature of bodies is necessary for a more sophisticated and realistic study of political claims-making related to bodies and sexualities, and of actual and potential change in the way our world is organised.

The articles presented here position themselves firmly within political science. For the ongoing debates on normative political theory, and the respective value of recognition, redistribution and representation for imagining a future with less inequalities, the political dynamics on trans* rights have much to offer. In contrast to more common understandings that locate trans* rights within political discourses of recognition, Platero (2020), Saeidzadeh and Strid (2020) and Elpes (2020) show the limits of such an understanding and a way out. The story of trans* rights in the Netherlands in particular highlights 
once more how political dynamics are not just about dynamics between political actors or between discourses that are explicitly and conventionally political. Precisely because medical knowledge is situated beyond the political realm, medical professionals wield political power. As their expertise is centred on the body, this means that any analysis of issues that are related to bodies needs to investigate the political role of these actors. So far, this has mainly been done for reproductive rights or so-called "morality policies" (Engeli, 2012), but the relevance for political science is wider.

The contributions to this thematic issue come from a highly diverse set of scholars, gendered in feminine, masculine or non-binary ways; junior and senior researchers, trans* and cis, "Western" and "non-Western," homoand heterosexual, and coming from different disciplines. This issue thereby reflects the interdisciplinary and diverse character of the field of trans* studies (Stryker, 2013). We hope that the readers will multiply the questions that are raised here, and that the articles in this thematic issue will provide a fertile ground for further scholarship and academic and political debate.

\section{Acknowledgments}

The authors are deeply grateful to all presenters, discussants and participants at the panel on "Trans* Politics: Current Challenges and Developments," at the ECPG in Amsterdam, 4-7 July 2019.

\section{Conflict of Interests}

The authors declare no conflict of interests.

\section{References}

Aboim, S. (2020). Gender in a box? The paradoxes of recognition beyond the gender binary. Politics and Governance, 8(3), 231-241.

Ashley, F. (2020). A critical commentary on 'rapid-onset gender dysphoria.' The Sociological Review, 68(4), 779-799.

Ayoub, P. (2016). When states come out: Europe's sexual minorities and politics of visibility. Cambridge: Cambridge University Press.

Ayoub, P., \& Paternotte, D. (2014). LGBT activism and the making of Europe: A rainbow Europe? London: Palgrave Macmillan.

Baars, G. (2019). Queer cases unmake gendered law, or, fucking law's gendering function. Australian Feminist Law Journal, 45(1), 15-62.

Babits, C. (2018). Review of nonbinary gender identities: History, culture, resources. Journal of Contemporary Archival Studies, 5(1), 15.

Balzer, C., \& Hutta, J. S. (2014). Trans networking in the European vortex: Between advocacy and grassroots politics. In P. Ayoub \& D. Paternotte (Eds.), LGBT activism and the making of Europe: A rainbow Europe? (pp. 171-192). London: Palgrave Macmillan.

Bettcher, T. M. (2016). Intersexuality, transgender and transsexuality. In L. Disch \& M. Hawkesworth (Eds.), The Oxford handbook of feminist theory (pp. 407-427). Oxford: Oxford University Press.

Bilić, B. (Ed.). (2016). LGBT activism and Europeanisation in the post-Yugoslav space: On the rainbow way to Europe. London: Palgrave Macmillan.

Booth, R. (2020, April 29). Transgender man loses appeal court battle to be registered as father. The Guardian. Retrieved from www.theguardian.com/society/ 2020/apr/29/transgender-man-loses-appeal-courtbattle-registered-father-freddy-mcconnell

Chappell, L. (2006). Contesting women's rights: Charting the emergence of a transnational conservative counter-network. Global Society, 20(4), 491-520.

Dalli, M. (2014, April 16). Transgender Europe applauds Malta for naming gender identity. Malta Today. Retrieved from www.maltatoday.com.mt/news/ national/38027/transgender_europe_applauds_ malta_for_naming_gender_identity\#.X1uwfmgzZPY

de Waele, H., \& van der Vleuten, A. (2011). Judicial activism in the European Court of Justice: The case of LGBT rights. Michigan State Journal of International Law, 19(3), 639-666.

Dunne, P. (2020). Chapter 11: Transgender rights in Europe: EU and Council of Europe movements towards gender identity equality. In C. Ashford \& A. Maine (Eds.), Research handbook on gender, sexuality and the law (pp. 137-147). Cheltenham: Edward Elgar.

Elpes, G. S. (2020). Trans* identities and politics: Repertoires of action, political cleavages, and emerging coalitions. Politics and Governance, 8(3), 301-311.

Engeli, I. (2012). Policy struggle on reproduction: Doctors, women, and Christians. Political Research Quarterly, 65(2), 330-345.

Helfer, L., \& Voeten, E. (2014). International courts as agents of legal change: Evidence from LGBT rights in Europe. International Organization, 68(1), 77-110.

Hervey, G. (2018, February 15). Bulgaria backs away from treaty opposing violence against women. Politico. Retrieved from https://www.politico.eu/ article/bulgaria-istanbul-convention-backs-awayfrom-treaty-opposing-violence-against-women

Hildebrand-Chupp, R. (2020). More than 'canaries in the gender coal mine': A transfeminist approach to research on detransition. The Sociological Review, 68(4), 800-816.

Hines, S. (2019). The feminist frontier: On trans and feminism. Journal of Gender Studies, 28(2), 145-157.

Human Rights Watch. (2008). OAS adopts resolution to protect sexual rights. Human Rights Watch. Retrieved from www.hrw.org/news/2008/06/05/oasadopts-resolution-protect-sexual-rights

Jeffreys, S. (1997). Transgender activism: A lesbian feminist perspective. Journal of Lesbian Studies, 1(3/4), 55-74.

Kabeer, N. (2015). Tracking the gender politics of the Mil- 
lennium Development Goals: Struggles for interpretive power in the international development agenda. Third World Quarterly, 36(2), 377-395.

Kollman, K., \& Waites, M. (2009). The global politics of lesbian, gay, bisexual and transgender human rights: An introduction. Contemporary Politics, 15(1), 1-17.

Meier, P., \& Motmans, J. (2020). Trans laws and constitutional rulings in Belgium: The ambiguous relations between sex and gender. Politics and Governance, 8(3), 242-252.

Monro, S., \& van der Ros, J. (2018). Trans* and gender variant citizenship and the state in Norway. Critical Social Policy, 38(1), 57-78.

O'Flaherty, M., \& Fisher, J. (2008). Sexual orientation, gender identity and international human rights law: Contextualising the Yogyakarta Principles. Human Rights Law Review, 8(2), 207-248.

Paternotte, D. (2018). Coming out of the political science closet: The study of LGBT politics in Europe. European Journal of Politics and Gender, 1(1/2), 55-74.

Pearce, R., Erikainen, S., \& Vincent, B. (2020). TERF wars: An introduction. The Sociological Review, 68(4), 677-698.

Platero, R. L. (2020). Redistribution and recognition in Spanish transgender laws. Politics and Governance, 8(3), 253-265.

Quinan, C. L., Molitor, V., van den Brink, M., \& Zimenkova, T. (2020). Framing gender identity registration amidst national and international developments: Introduction to 'Bodies, identities, and gender regimes: Human rights and legal aspects of gender identity registration.' International Journal of Gender, Sexuality and Law, 1(1), 1-25.

Saeidzadeh, Z., \& Strid, S. (2020). Trans* politics and the feminist project: Revisiting the politics of recognition to resolve impasses. Politics and Governance, 8(3), 312-320.

Serano, J. (2020). Autogynephilia: A scientific review, feminist analysis, and alternative 'embodiment fantasies' model. The Sociological Review, 68(4), 763-778.

\section{About the Authors}

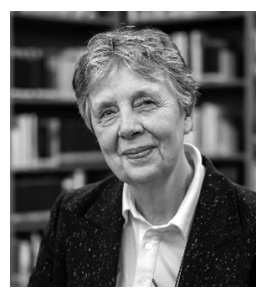

Mieke Verloo is Professor of Comparative Politics and Inequality Issues at the Department of Political Science, Radboud University, Nijmegen, and Non-Residential Permanent Fellow at the IWM, Institute for Human Sciences in Vienna. Recent publications: Varieties of Opposition to Gender Equality in Europe (Routledge, 2018); "The Feminist Project under Threat in Europe," (Politics and Governance, thematic issue co-edited with David Paternotte); "Political Science at Risk in Europe: Frailness and the Study of Power" (chapter co-authored with David Paternotte, in Political Science in Europe: Achievements, Challenges and Prospects, Rowman \& Littlefield, 2020).

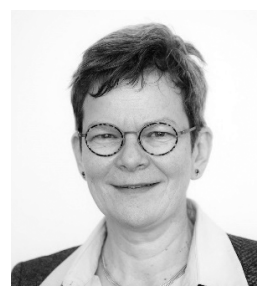

Anna van der Vleuten is Professor of Contesting Europeanization the Department of Political Science, Radboud University, Nijmegen. Her research focuses on EU gender equality policies, contestations of gender(ed) norms and LGBTI rights, EU external relations, and comparative regionalism. Recent publications include a special issue on “Gender Equality in European Union's External Relations in Times of Crisis" (co-edited with Hanna Muehlenhoff and Natalie Welfens, Political Studies Review, 18(3), 2020). 